\title{
Meniscal allograft transplantation in rabbit
}

\author{
LIANA M. VILELA, RICARDO J. DEL CARLO, EDSON V. MELO FILHO, LUKIYA S.C. \\ FAVARATO, TATIANA S. DUARTE, KELLY C.S. PONTES and DAISE N.Q. CUNHA
}

\author{
Departamento de Veterinária, Universidade Federal de Viçosa, Avenida PH Rolfs, s/n, 36570-000 Viçosa, MG, Brasil
}

Manuscript received on August 27, 2014; accepted for publication on January 30, 2015

\begin{abstract}
This study evaluated the technique for meniscal allograft transplantation using allografts preserved in glycerin $98 \%$ in rabbits. Euthanasia was performed at 70 days to compare the transplanted (TM1 to TM16) versus the contralateral meniscus (OM1 to OM16). Sixteen menisci, 8 transplanted and 8 contralateral, were submitted to gross examination, histomorphometric analysis for identification and quantification of cellular type, and for quantification and distribution of collagen fibers. A revascularization study was conducted in all of the other samples. Lengths of the OM varied from 0.9 to $1.0 \mathrm{~cm}$ and two TM were smaller. All TM were completely attached to the synovial membrane, except for one case that presented partial fixation. Both, TM and OM had similar amounts of chondrocytes, fibroblasts and fibrocytes, and at the horns, chondrocytes were predominant. The collagen fibers in TM were well organized throughout the body, and disorganized at the horns. These fibers in OM were organized. The amounts of collagen type I and III, and the vascularization of the perimeniscal tissue and of the edge were similar in OM and TM. These results demonstrated graft integration and thus this transplantation technique and preservation method may be recommended.
\end{abstract}

Key words: knee, meniscal allograft, survival analysis, transplantation, revascularization.

\section{INTRODUCTION}

The menisci are fibrocartilaginous structures that intervene between the condyles of the femur and tibia, and are susceptible to traumatic lesions, progressive joint degeneration, or to spontaneous progressive structural failure due to fatigue (Camanho 2009).

The extracellular matrix of the menisci consists of collagen fibers, proteoglycans, elastin, and water (Reckers et al. 2009). Total collagen is made up of about $70-80 \%$ collagen type I, while the remaining

Correspondence to: Daise N.Q. Cunha

E-mail: daisenunes@gmail.com portion consists of collagen type II, III, V, and VI. The glycosaminoglycan are important to maintain the viscoelastic behavior, flexibility and hydration of the tissue (Rijk and Van Noorden 2002, Buma et al. 2004, Vilela et al. 2010b, 2013).

The diameter and orientation of the collagen fibers and the cell morphology, differ from the surface to the deep central regions of the meniscus. The surface against the articular cartilage generally consists of thin fibrils and underneath them there are collagen fibers of small diameter oriented in a radial fashion towards the meniscus, where a thicker layer of collagen is formed (Ghadially et al. 1983). 
The horns of the meniscus are supplied with blood vessels and nerves with large myelin sheaths, while the body virtually lacks these structures (Arnoczky and Warren 1982, Cohen et al. 1993), thus receiving its nourishment by diffusion of the synovial liquid (Arnoczky and Warren 1983).

Repairing of the meniscus can be done if the cranial cruciate ligament is intact and if the lesion is small and located in a vascularized area. When the criteria for suturing are not fulfilled, a partial or total meniscectomy must be performed (Cury et al. 2002) resulting in various degrees of articular cartilage damage (Wirth et al. 2002, Rijk 2004).

One great advantage of allograft transplantation is the possibility of using tissue with similar morphology to the one being replaced; on the other hand there are disadvantages, such as transmission of contagious diseases, slow graft remodeling, and eventually, rejection (Buma et al. 2004, Reckers et al. 2005, Xing et al. 2005, Tucker et al. 2012).

Some authors believe that cellular viability is an important factor for graft integration, others prefer to transplant the meniscus using devitalized collagenous matrix (Rijk 2004, Reckers et al. 2005).

The type and length of preservation have direct diverse effects on the cellular activity, the biological integrity and the tissue biochemistry. The most commonly used techniques are refrigeration, freezing, lyophilization, and cryopreservation (Friedman 2003) and preservation on glycerin 98\% (Vilela et al. 2010a, b, 2013).

The aim of the present study were: 1 - to evaluate the surgical transplantion of the allograft meniscus, 2- to evaluate the transplant revascularization, 3to determine the size of the meniscus, and 4- to quantify the types of the collagen fibers and its organization pattern.

\section{MATERIALS AND METHODS}

Sixteen male New Zealand white rabbits, weighing $3.5 \mathrm{~kg}$ were used. All procedures were approved by the Ethics Committee on Animal Experimentation (protocol number 89/2007). The principles observed in this study are described in the European Convention for the Protection of Vertebrate Animals and in the National Research Council Guide for the Care and Use of Laboratory Animals.

The experiment was divided into three parts. First, the left meniscus was aseptically collected from 16 rabbits with similar body sizes obtained from a commercial source. Each meniscus was individually maintained in containers filled with $98 \%$ glycerin for 45 to 60 days, according to procedures described by Vilela et al. (2010a).

In the second part, the meniscus preserved in glycerin was re-hydrated for $12 \mathrm{~h}$ in saline solution with $0.5 \%$ enrofloxacin and transplanted to a new rabbit after having total medial meniscectomy of the left knee.

The third part of the study began 70 days after the transplant. Rabbits were submitted to euthanasia and the transplanted meniscus (left knee) was removed. The transplanted meniscus was called 'treated meniscus' $\left(\mathrm{TM}_{1}\right.$ to $\left.\mathrm{TM}_{16}\right)$ and the contralateral (right knee) was called 'other meniscus' $\left(\mathrm{OM}_{1}\right.$ to $\left.\mathrm{OM}_{16}\right)$.

Sixteen menisci, eight treated and eight contralateral, were submitted to macroscopic and histomorphometric analysis by quantification of the types of collagen fibers, evaluation of its disposition, and quantification of the cells types. The other 16 menisci, eight treated and eight contralateral, were submitted to a vascularization study using contrast radiographs.

For the surgical procedures animals were sedated with acepromazine $0.2 \%(0.5 \mathrm{mg} / \mathrm{kg}$, IM). All animals received anti-inflammatory medication with meloxicam $0.2 \%(0.2 \mathrm{mg} / \mathrm{kg}$, SC) and antimicrobial therapy with enrofloxacin $2.5 \%(10 \mathrm{mg} / \mathrm{kg}, \mathrm{SC})$. Anesthesia was induced with midazolam $(3 \mathrm{mg} / \mathrm{kg})$ and ketamine $(25 \mathrm{mg} / \mathrm{kg})$ 
IM, and maintained with isofluarane delivered by mask in a constant flow of oxygen $(2.5 \mathrm{~L} / \mathrm{min})$.

A longitudinal incision of approximately $6 \mathrm{~cm}$ on the skin and subcutaneous tissue was performed in the cranial-medial surface of the left knee. Following, the subcutaneous tissue was dissected until exposure of the medial articular capsule; the latter was cut together with the synovial membrane. The patella was laterally pulled, and the knee flexed, exposing the joint. The contralateral medial ligament and the patellar tendon were briefly kept to one side using nylon to facilitate the visualization of the meniscus and the sectioning of the meniscocapsular ligaments. Following, a discrete effort in valgus with the flexed knee was sufficient to allow a caudal approach of the medial meniscus. A total medial meniscectomy was performed after sectioning of the cranial and caudal meniscotibial ligaments.

Prior to the transplantation, using polyglactin 910 , number 6.0 and hypodermic needle $13 \times 0.45$, each meniscus was transfixed using two horizontal mattress sutures, one in the region between the cranial horn and the medium third of the meniscus, and the other between the midway and the caudal horn (Fig. 1a, b).
The meniscus was positioned on the tibial plateau and the sutures were passed from the interior to the exterior of the articular capsule. The suture in the caudal portion of the meniscus caudally positioned to the collateral medial ligament and the suture in the cranial portion was laterally positioned in the patellar tendon, passing through the articular capsule (Fig. 2a, b). Then, the skin was sustained apart allowing visualization of the sutures, the knots were tied on the subcutaneous tissue, and the meniscus was fixed. Following, the patella was repositioned, and the articular capsule and subcutaneous tissue were sutured with polyglactin $910,4.0$. The skin was sutured with mononylon 4.0 in a simple interrupted pattern.

After the surgical procedure, each rabbit received morphine $(1.0 \mathrm{mg} / \mathrm{kg}, \mathrm{SC}) \mathrm{q} 8 \mathrm{~h}$ for 2 days, enrofloxacin (10 mg/kg, IM) q24h during 8 days, and meloxicam $(0.2 \mathrm{mg} / \mathrm{kg}, \mathrm{SC})$ for 4 days. The surgical wound was evaluated daily until the sutures were removed after 10 days. Each animal was maintained in individual cages (60X40X40) and were allowed to move freely for 70 days.

Seventy days after the transplant, rabbits were submitted to euthanasia using anesthetic overdose, and both treated $\left(\mathrm{TM}_{1}\right.$ and $\left.\mathrm{TM}_{16}\right)$ and contralateral $\left(\mathrm{OM}_{1}\right.$ and $\left.\mathrm{OM}_{16}\right)$ menisci were removed.

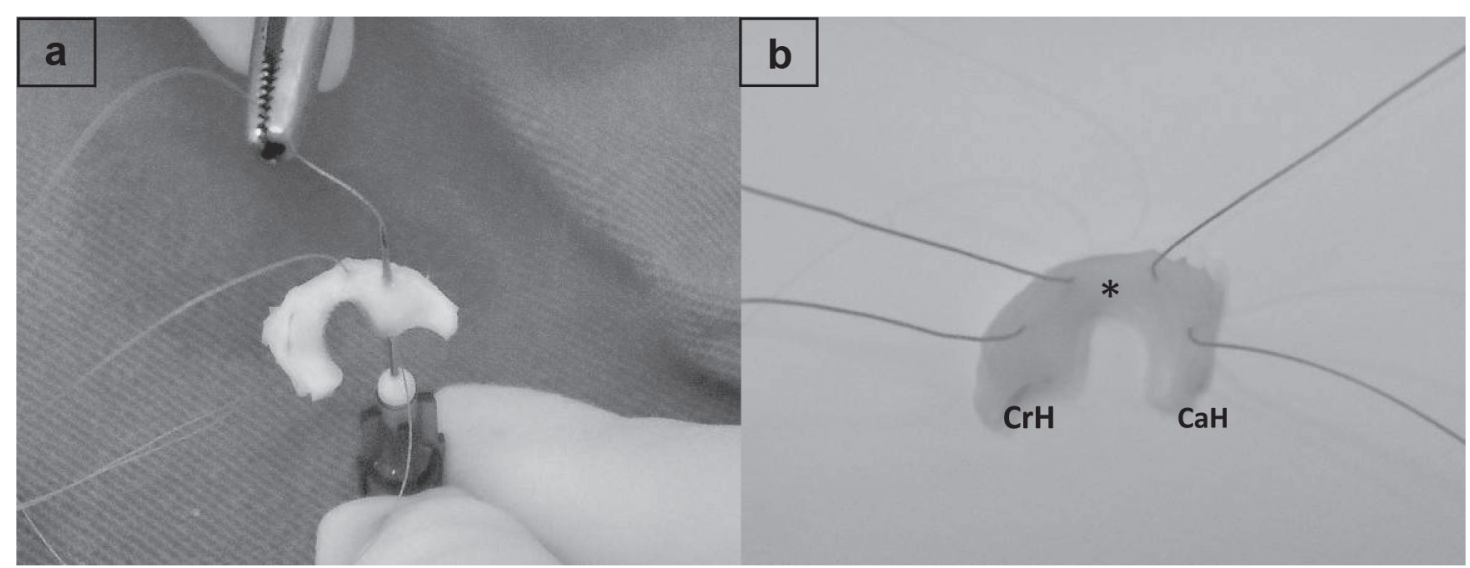

Figure 1 - Surgical sutures applied to the meniscus. a: meniscus being transfixed with two horizontal mattress knots with the aid of hypodermic needle $13 \times 0.45$. b: meniscus with suture inserted between the middle third and the cranial horns $(\mathrm{CrH})$ and caudal $(\mathrm{CaH}){ }_{*}$ Middle third. (See the colors in the online version). 


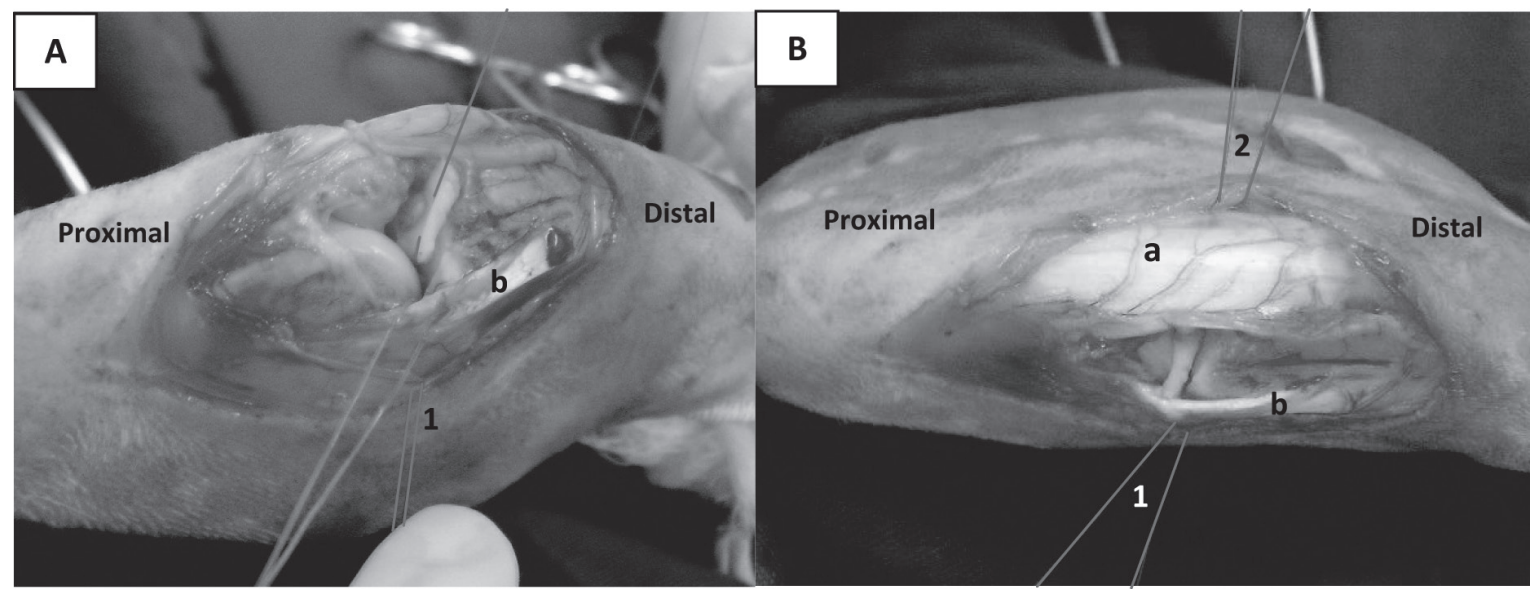

Figure 2 - Meniscal implantation and fixation to the joint. A: meniscus positioned on the tibial plateau. B: Sutures passed through from the inside to the outside of the joint. Patellar tendon (a); medial colateral ligament (b); suture caudal to the medial colateral ligament (1); suture lateral to the patellar tendon (2). (See the colors in the online version).

\section{GROSS EVALUATION}

The size, shape and peripheral fixation of the treated (TM) menisci were evaluated. The TM was categorized as normal when presenting the same size and shape of the contralateral meniscus, and as altered when the size and shape were different. The peripheral fixation was termed as total, if the whole meniscus was fixed to the synovial membrane, and as partial if at least one portion of the meniscus was not adhered.

\section{MICROSCOPIC EVALUATION}

After microscopic evaluation, the menisci were processed for histological analysis. The histological sections were stained using the hematoxylin-eosin (HE) for cell evaluation, and Picrosirius Red, for identification and quantification of the collagen fibers type I and III.

For cellularity evaluation, ten images were captured (20X) from each slide stained with HE and evaluated using a special software (Image Pro-Plus4.5). Cell types (fibroblasts/fibrocytes and chondrocytes) were identified and quantified using 1000 intersections, randomly selected in each slide. The distribution of the cells was also evaluated and classified as being located in the periphery, in the central or throghout the meniscus.
The slides stained with Picrosirius were evaluated for collagen type and collagen distribution using polarized light microscopy (Olympus AX70) $10 X$.

Ten images were captured from different fields for each meniscus and analyzed for total collagen type I and III using Image Pro-Plus4.5.

A grid with 100 intersections was placed on each image and the points in red, orange or yellow, representing type I collagen fibers, and the points in green, representing type III fibers were counted. The percentage of each color representing the types of collagen was established and the disposition of these fibers was categorized as organized or not.

\section{VASCULARIZATION EVALUATION}

Prior to removal of the menisci (TM and OM), a contrast media was injected in the right and left femoral artery. A longitudinal incision of $6.0 \mathrm{~cm}$ in the medial portion of the thigh was made, followed by dissection of the subcutaneous tissue until the muscle plane. The vastus medialis muscle was retracted laterally and the sartorius muscle was medially pulled reaching the neurovascular bundle.

After being isolated, a ligature was distally placed in the femoral artery and a catheter $n^{\circ} 24$ was inserted. The collateral vessels were obliterated to avoid leakage of contrast media. A tourniquet 
was placed juxta-proximal to the point of catheter introduction, in the proximal third of the femur, and another was distally placed, in the medium third of the tibia with the purpose of increasing the periarticular pressure. Then, euthanasia was performed and $10 \mathrm{~mL}$ of barium sulphate $100 \%$ (Bário Gel Geléia, Cristália) was gradually and slowly infused.

At the end of the injection, the catheter was clamped and the tourniquets were maintained. Following, a meniscectomy was skillfully performed preserving the anatomy of the menisci and its capsule. The meniscus was placed in formalin $10 \%$ and preserved for 10 days for $\mathrm{x}$-rays.

The treated (TM) and contralateral (OM) menisci were submitted to radiography using a mammography equipment (General Electric, Senographe 700t), with mammography film. An exposure time of $25 \mathrm{kv}$ and $0.3 \mathrm{~s}$ was used. Posteriorly, the radiographs of both groups TM and OM were observed and compared for the presence or absence of perimeniscal tissue vascularization and peripheral margin.

\section{STATISTICAL ANALYSES}

The percentage of cellularity and collagen between $\mathrm{OM}$ and TM was compared using non-parametric Mann-Whitney test due to the low number of observations. P values lower than 0.05 indicated that the differences were significant between groups. Statistical calculations were performed using SPSS v18.0.

\section{RESULTS}

Two treated menisci (TM1 and TM6) had smaller lengths (Table I) in its greater axis $(0.6$ and $0.7 \mathrm{~cm}$, respectively) compared to the contralateral menisci whose length varied from 0.9 to $1.0 \mathrm{~cm}$. The other six treated menisci had similar length to the contralateral menisci. In addition, TM1 presented a circumferential shape as the cranial horn integrated with the caudal, different from the contralateral menisci which presented an oval shape.

Only TM1 presented a partial fixation, in which the caudal horn and medium third were free. In this case the meniscus was fixed by the cranial horn. The other seven treated menisci were entirely fixed to the articular capsule (Table I).

Animals were submitted to euthanasia at the $70^{\text {th }}$ day, and by then there were no clinical signs of claudication, no evidence of swelling, no presence of effusion, no rubor or any signs of sensitivity present in the femur-tibia-patella articulation. Furthermore, the histopathological exam performed at the graft fixation site did not reveal vascular reaction, infiltration and/or cellular exudation that could suggest or indicate the existence of an inflammatory reaction.

In both, $\mathrm{OM}$ and $\mathrm{TM}$, chondrocytes were the prevalent cell type, present in larger quantity at the horns and involved in abundant amount of interstitial substance (Fig. 3a-h). The fibroblasts/ fibrocytes were mainly present in the body of the meniscus (Fig. 4-f).

TABLE I

Size, shape and peripheral characteristics of treated meniscus.

\begin{tabular}{cccc}
\hline Meniscus & Size & Shape & Periph. characteristics \\
\hline TM1 & Altered & Altered & Partial \\
TM2 & Normal & Normal & Total \\
TM3 & Normal & Normal & Total \\
TM4 & Normal & Normal & Total \\
TM5 & Normal & Normal & Total \\
TM6 & Altered & Normal & Total \\
TM7 & Normal & Normal & Total \\
TM8 & Normal & Normal & Total \\
\hline
\end{tabular}



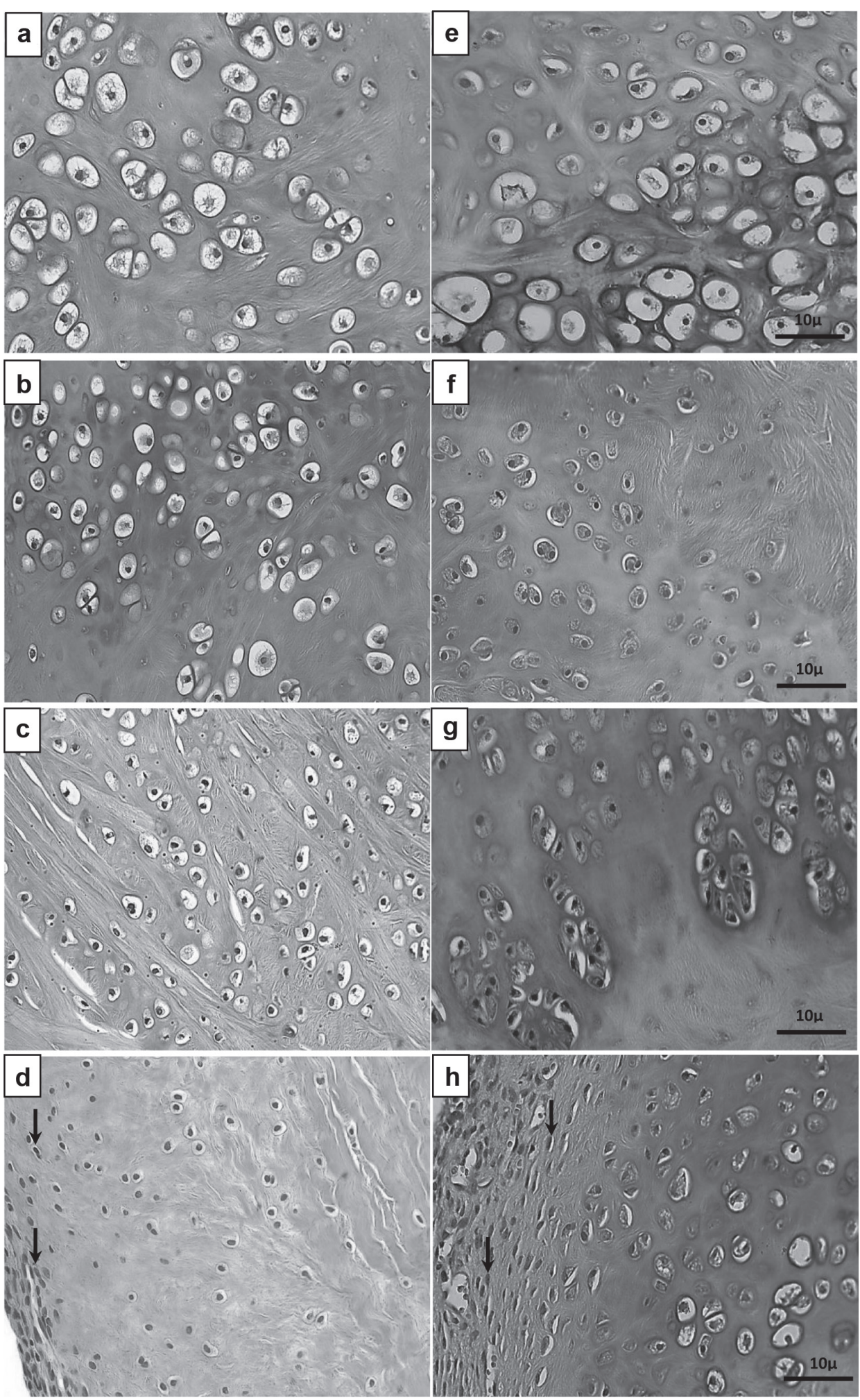

Figure 3 - Photomicrographs of the horns from the contralateral (a, b, c and d) and treated menisci $(\mathbf{e}, \mathbf{f}, \mathbf{g}$ and $\mathbf{h}$ ), showing chondrocytes involved by intersticial substance. In figures $\mathbf{d}$ and $\mathbf{h}$, fibroblast and fibrocytes (arrows) are observed in the peripheral regions of the horns and chondrocytes in the central region. HE. (See the colors in the online version). 

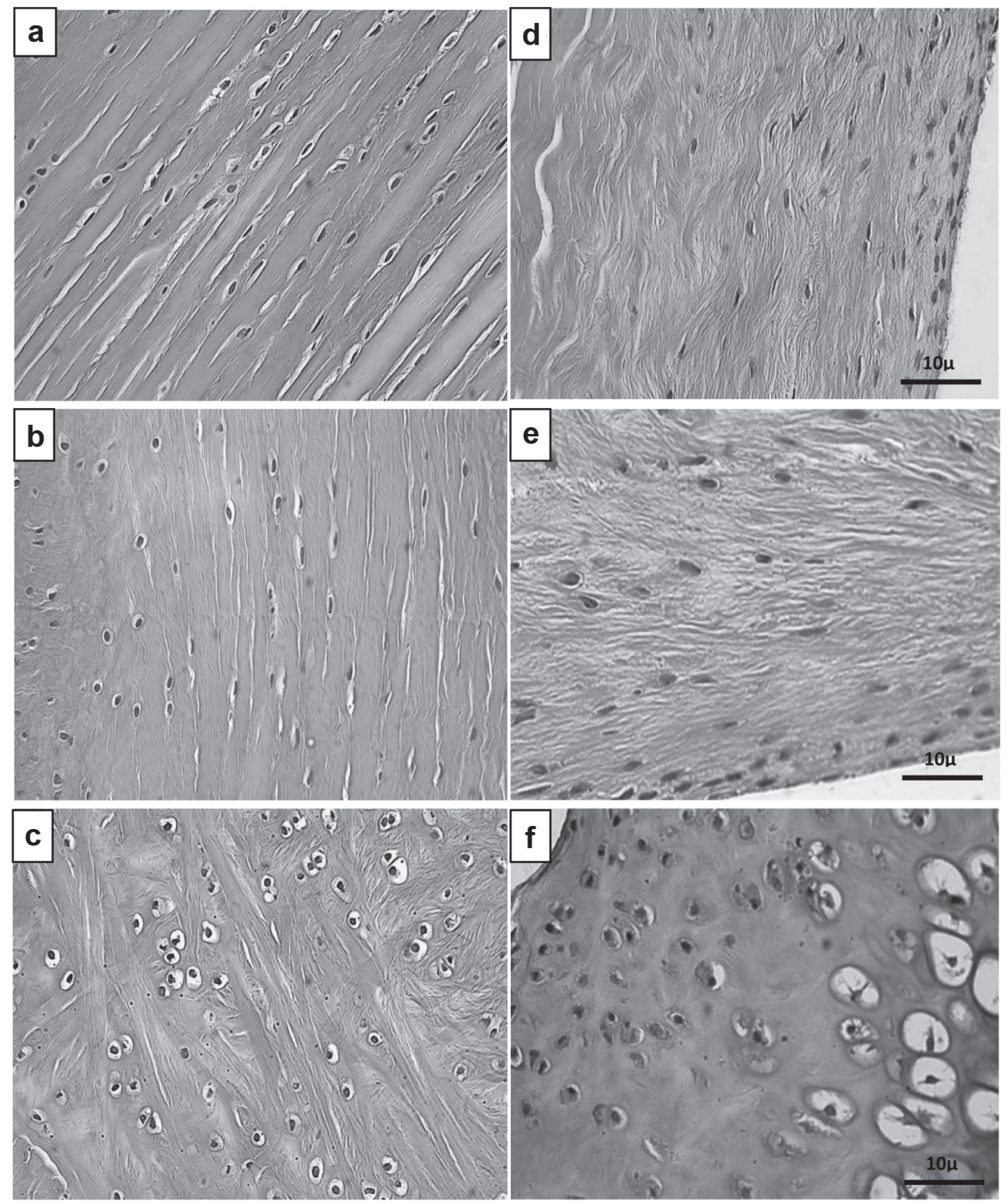

Figure 4 - Photomicrographs of the horns of the contralateral (a and $\mathbf{b}$ ) and treated menisci (d and e), showing the presence of fibrocytes and fibroblasts in the peripheral and central regions. In $\mathbf{c}$ (contralateral) and $\mathbf{f}$ (treated) chondrocytes are scattered throughout the body of the meniscus. HE. (See the colors in the online version).

There were no differences $(P<0.05)$ in the percentage of chondrocytes and fibroblasts/ fibrocytes between the contralateral (OM) and treated (TM) menisci, as the average values were 60.5 and 39.5 for OM, and 59.4 and 40.6 for TM, respectively.

The arrangement of the collagen fibers was organized in the body and disorganized in the horns of the meniscus. Differently, OM presented fibers well organized throughout the entire meniscus (Fig. 5a-f). The collagen fibers were predominantly arranged in a circumferential pattern interwittened with a few fibers radially positioned. These patterns were observed in the body of the TM and throughout the OM. The TM had disorganized fibers in the horns. 

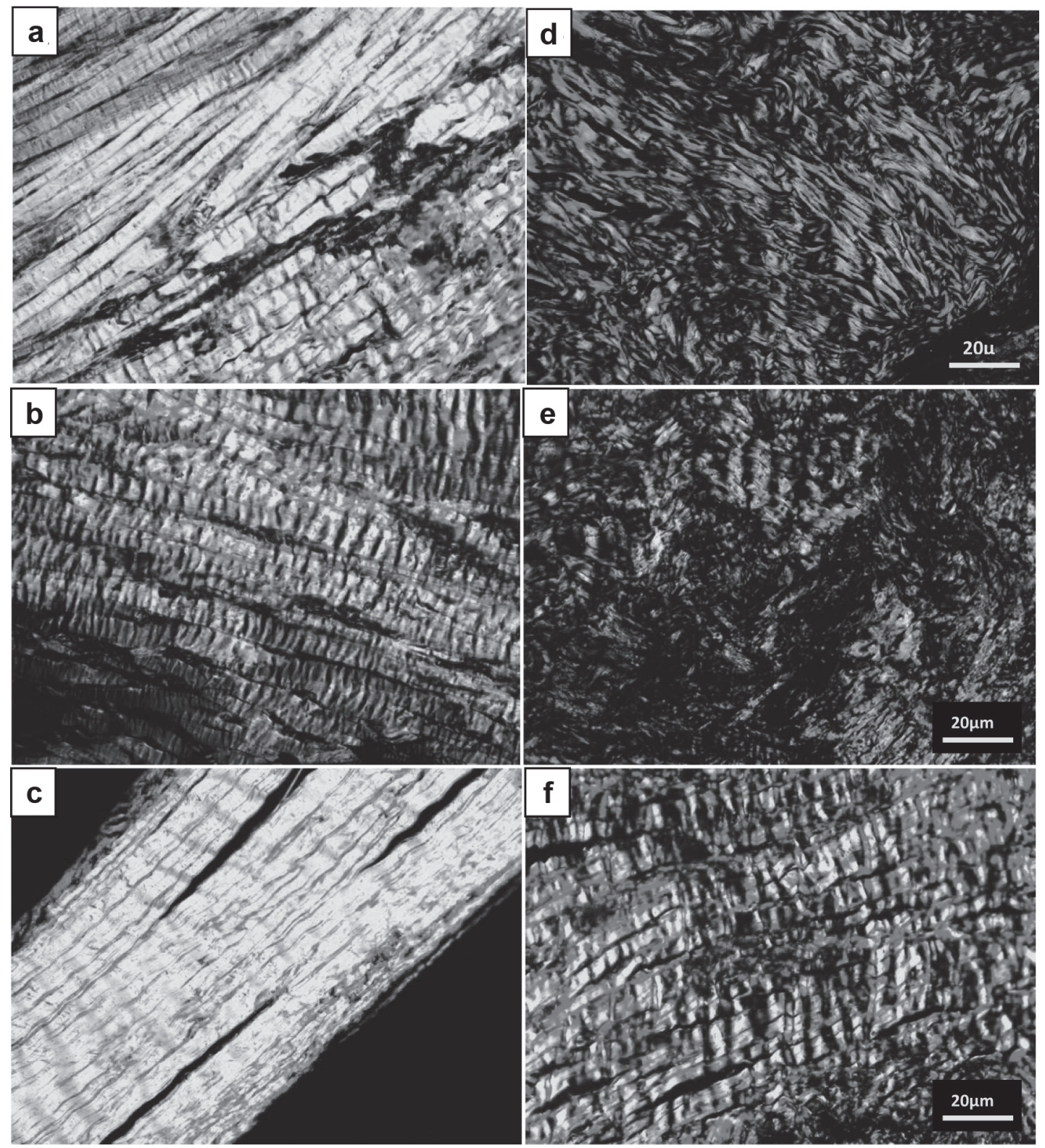

Figure 5 - Fotomicrographs of collagen fibers observed under polarized light microscopy. Type I collagen fibers: yellow, orange and reddish color; type III: green color. Organized collagen fibers were observed in the horns (a and b) and in the body (c) of the contralateral menisci (OM). In the treated menisci (TM), the fibers were found to be disorganized in the horns (d and e) and organized for the majority of the fibers present in the body (f). Picrosirius Red. (See the colors in the online version).

Type I fibers predominated in both treated and contralateral menisci, with percent average of 66.8 and 70.9, respectively. Type III collagen was $29.1 \%$ in OM and $33.2 \%$ in TM, demonstrating that collagen type I or III did not differ between OM and TM.
The vascularization study demonstrated that vessels were located in the perimeniscal tissue (synovial membrane, capsule, and adipose tissue) and in the peripheral edge of the horns and/or body of the meniscus (Fig. 6). Blood vessels were visualized in the central region of the meniscus 

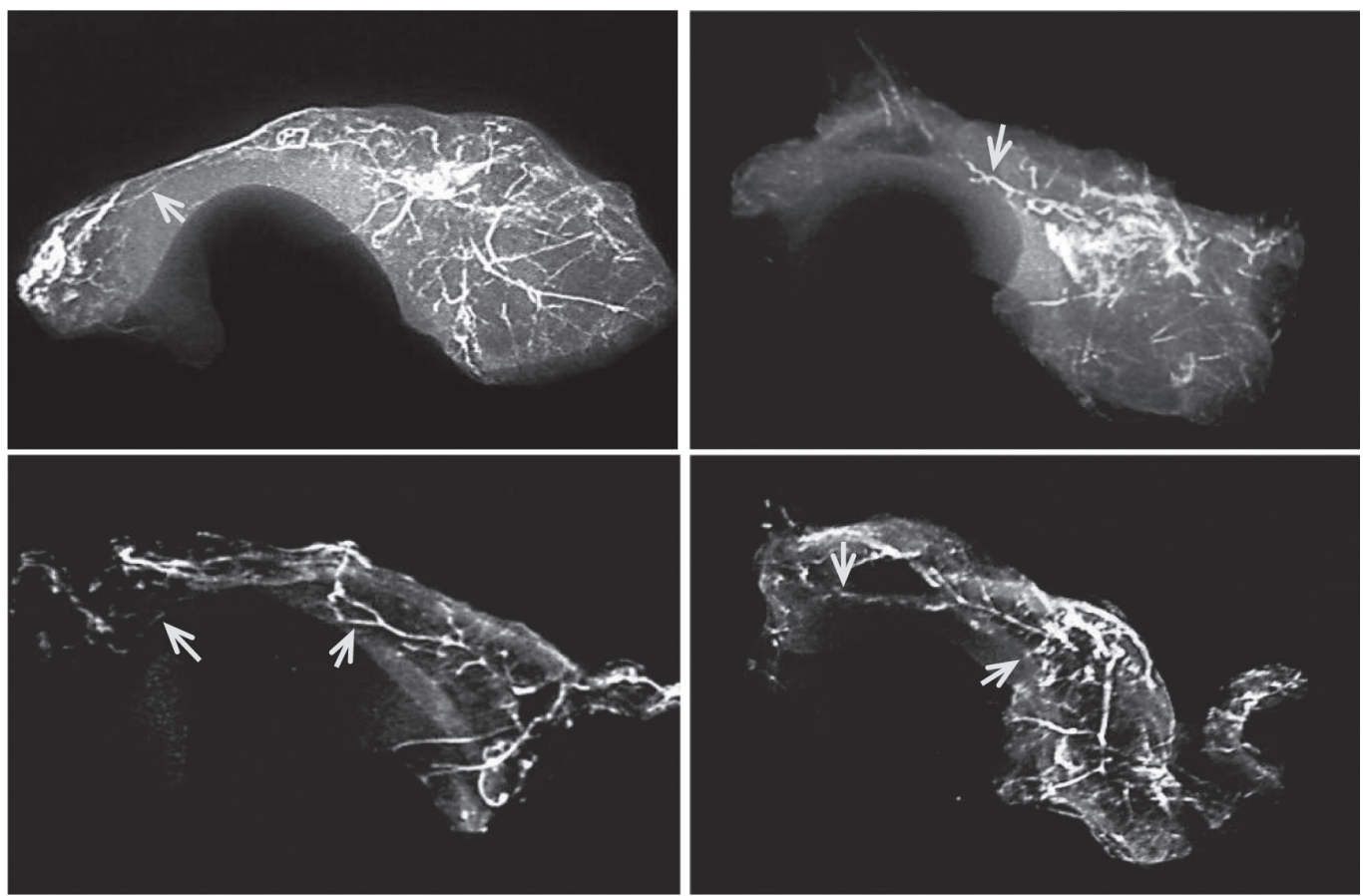

Figure 6 - Contrasted radiographs of treated menisci (TM), showing vascularization of the perimeniscus tissue and peripheral edge of the meniscal body and horns (arrows). (See the colors in the online version).

during histological evaluation using HE. Both, OM and TM had similar vascular patterns.

\section{DISCUSSION}

The main advantage of using meniscal allograft transplantation preserved in glycerin is to have similar morphology of the removed tissue.

Cury et al. (2002) recommend meniscectomy and replacement of the meniscus by allograft transplant in situations where suturing of the meniscus is not feasible or if there is loss of meniscal tissue.

In the present study, the transplanted meniscus was fixed to the articular capsule using polyglactin $(910,6.0)$ applied to the meniscus from the inside to the outside of the joint. Cury et al. (2002) used similar technique in rabbits, but used nylon 6.0, also obtaining stable fixation, which is an important step for the stabilization and success of the transplant.

In regards of the peripheral fixation, TM1 had partial fixation because the meniscus was only fixed by the cranial horn, while the caudal horn and the middle third were detached. The suture was probably removed or cut through the meniscus at the time of the ligature, or was absorbed. The partial fixation could explain the altered shape of TM1. The other seven treated menisci presented complete fixation, in other words, the entire peripheral region was fixed to the articular capsule. These results were similar to those of Mikic et al. (1993) in dogs and Cury et al. (2002) in rabbits, who found a high percentage of fixation throughout the peripheral margins of the transplanted menisci, but also reported cases of absent fixation in the middle third and caudal horn.

The final evaluations in this study were performed at 70 days based on previous studies. Researchers (Somer and Somer 1983, Vilela et al. 2010a) evaluated collagen fibers and cellular types, and found cellular repopulation around 70 days following the implant. Others (Cury et al. 2002) conducted a vascularization study on implanted homologous meniscus at 70 days. 
Chondrocytes were the predominant cell type in both contralateral and treated meniscus, with greater prevalence in the horns, and enclosed by abundant interstitial substance. According to Ghadially et al. (1978), Cury et al. (2002) and Vilela et al. (2010a), the rabbit meniscus is composed of intertwined collagen fibers interposed by the cellular types, which was also observed in the present study. The presence of fibroblasts/fibrocytes mainly in the body of the meniscus demonstrates that the TM meniscus was repopulated by similar cell types and at similar locations as OM. Somer and Somer (1983) and Vilela et al. (2010a), had analogous findings in fresh meniscus of dogs and rabbits, respectively. However, these results differed from those obtained by Cury et al. (2002) because they did not observe the predominance of one particular cell type. Instead, the latter group observed a homogenous distribution of cells in allograft transplantation of frozen meniscus in rabbits.

The percentage of chondrocytes and fibroblasts/fibrocytes between the contralateral and treated menisci was similar to the values reported by Vilela et al. (2010a), in fresh meniscus of rabbits. According to Mikic et al. (1997) and Starke et al. (2009), after transplant, the meniscal allograft is popularized by the host cells from the synovial membrane and articular capsule.

In this study, the meniscal allografts were preserved in glycerin $98 \%$ and rehydrated in saline prior to transplantation. According to Vilela et al. (2010a), when the meniscus is submitted to such preservation method, a loss of cellular viability occurs, but Reckers et al. (2005) demonstrated that this was not observed after applying the freezing technique. Thus, if a devitalized collagenous matrix is desired for meniscal allograft transplant, the glycerin $98 \%$ demonstrated to be a reliable preservation media, as recommended by Aagaard and Verdonk (1999).

In the TM, collagen fibers were found to be organized in the body and disorganized in the horns.
In the OM, these fibers were organized throughout the entire meniscus. Arnoczky et al. (1992) and Cury et al. (2002) also found similar alterations in the disposition of collagen fibers in meniscal allografts of dogs and rabbits. These researchers also concluded that the observed disorganization, mainly in the third month after transplantation, was only temporary and resultant of tissue remodeling, disappearing six months after the transplant.

The collagen fibers presented a predominantly circumferential pattern interwittened with a few fibers radially positioned in the body of the treated meniscus and throughout the contralateral meniscus, similar to the histological organization found in fresh meniscus of rabbits, described by Vilela et al. (2010b). It has been emphasized (Aagaard and Verdonk 1999, Rijk and Van Noorden 2002, Vilela et al. 2013) that this disposition of collagen fibers contributes to the maintenance of the mechanical properties. In the TM, fibers were disorganized in the horns of the menisci, which could compromise the mechanical capabilities of the transplant in the first 6 months, a period that tissue remodeling occurs Xing et al. (2005).

The predominance of collagen fibers type I, both in the contralateral and in the treated meniscus, illustrates that the type of collagen predominance was maintained in the preserved allograft and after transplantation, agreeing with McDevitt and Webber (1990) and Buma et al. (2004). However, Reckers et al. (2009) observed that the percentage of collagen type I varied from 23.7 to $34.5 \%$ in meniscus allograft of rabbit preserved at $-73{ }^{\circ} \mathrm{C}$, which could negatively impact the mechanical properties of the transplant.

The presence of vascularization in the perimeniscal tissue and peripheral edge of the horns and/or body of the meniscus demonstrated the invasion of the meniscal allograft by blood vessels from the host, initiated from the synovial membrane and articular capsule, allowing for repair/fixation of the transplant. 
The lack of vascularization of the central region of the TM does not necessarily result undesirable consequences, because the OM also presented similar vascularization pattern in this region. Furthermore, the literature (Arnoczky and Warren 1983) describes the central region of the meniscus as being avascular and nourished by diffusion of synovial fluid, while the vascular synovial plexus from the articular capsule irrigates the peripheral area of the body.

A methodological limitation was due to the locomotion pattern of the rabbit. This precluded the evaluation of movements during recovery. However, this limitation did not interfere with the morphological evaluations in this study.

Although the Sirius Red method is frequently used to differentiate collagen fibres I and III (Junqueira et al. 1978, 1979, Montes et al. 1980, Zambrano et al. 1982), as well as in situ measurement of collagen synthesis by human bone cells (i.e. human osteoblastic-like cell culture) (TulbergReinert and Jundt 1999), most histochemical stains are open to the criticism of artefact. Nevertheless, it is noteworthy that similar to what has been pointed out by using the Sirius Red method, fine and coarse birefringent fibers were identified as separate and distinctive features in the extracellular matrix by antibodies raised against human collagen Type III (Carter et al. 1991).

\section{CONCLUSIONS}

The surgical technique comprising two horizontal mattress sutures is efficient for the meniscal intraarticular fixation. Additionally, 70 days after the transplant, the histological analysis and radiographs demonstrated the incorporation of the glycerinpreserved medial meniscal allograft in rabbits.

\section{ACKNOWLEDGMENTS}

R.J. Del Carlo was funded by Conselho Nacional de Desenvolvimento Científico e Tecnológico (CNPq).

\section{RESUMO}

Este estudo avaliou a técnica do alotransplante de menisco utilizando enxertos preservados em glicerina a $98 \%$, em coelhos. A eutanásia foi realizada depois de 70 dias para comparar os meniscos transplantados (TM1 a TM16) versus os contralaterais (OM1 a OM16). Dezesseis meniscos, 8 TM transplantados e 8 $\mathrm{OM}$ contralaterais foram submetidos à análise macro e histomorfométrica para identificação e quantificação do tipo celular, e para a quantificação e distribuição das fibras colágenas. Um estudo de revascularização foi feito em todas as outras amostras. O comprimento dos OM variou de 0,9 1,0 cm e, em dois TM, foi menor. Todos os TM estavam completamente fixados à membrana sinovial,exceto por um caso que apresentou fixação parcial. Em ambos, TM e OM foi encontrada a mesma quantidade de condrócitos, fibroblastos e fibrócitos, mas os condrócitos estavam predominantes no corno. Em TM, as fibras de colágeno estavam distribuídas de forma organizada em todo o corpo, e desorganizada nos cornos. Em OM, estas fibras estavam bem organizadas. A quantidade de colágeno tipo I e III, e a vascularização do tecido perimeniscal e da borda foram semelhantes em OM e TM. As avaliações mostraram a incorporação do enxerto e recomendam esta técnica de transplante e o método de preservação.

Palavras-chave: joelho, aloenxerto meniscal, análise de sobrevivência, transplante, revascularização.

\section{REFERENCES}

AAGAARD H AND VERDONK R. 1999. Function of the normal meniscus and consequences of meniscal resection. Scand J Med Sci Spor 9: 134-140.

ARNOCZKY SP, DICARLO EF, O'BRIEN SJ AND WARREN RF. 1992. Cellular repopulation of deep-frozen meniscal autografts: an experimental study in the dog. Arthroscopy 8: 428-436.

ARNOCZKY SP AND WARREN RF. 1982. Microvasculature of the human meniscus. Am J Sports Med 10: 90-95.

ARNOCZKY SP AND WARREN RF. 1983. The microvasculature of the meniscus and its response to injury. An experimental study in the dog. Am J Sports Med 11: 131-141.

BUMA P, RAMRATTAN NN, VAN TIENEN TG AND VETH RPH. 2004. Tissue engineering of the meniscus. Biomaterials 25: $1523-1532$.

CAMANHO GL. 2009. Meniscal injury due to fatigue. Acta Ortop Bras 17: 31-34.

CARTER DH, SLOAN P AND AARON JE. 1991. Immunolocalization of collagen types I and III, tenascin, and 
fibronectin in intramembranous bone. J Histochem Cytochem 39: 599.

COHEN M, ABDALLA RJ, BARRETO FAQM, BOUCHABKI ET, OliveIRA EC AND EJNISMAN B. 1993. Estudo radiográfico experimental da vascularização de meniscos humanos. Rev Bras Ortop Trau 28: 263-272.

CUry RPL, CAMARgo OPA, Prospero JD, BotTer FCS, SEVERINO NR, AIHARA T AND OLIVEIRA VM. 2002. Transplante Homólogo de menisco: estudo experimental em coelhos. Rev Bras Ortop 37: 341-350.

FRIEDMAN MD. 2003. Meniscal Allografts. Arthroscopy 18: 33-39.

GHadially FN, LALONDE JA AND WedGE JH. 1983. Ultrastructure of normal and torn menisci of the human knee joint. J Anat 136: 773-791.

GHADIALLY FN, THOMAS I AND YONG N. 1978. Ultrastructure of rabbit semilunar cartilages. J Anat 125: 499-517.

JUNQUEIRA LCU, BIGNOLAS G AND BRENTANI R. 1979. Picrocirius staining plus polarization microscopy - a specific method for collagen detection in tissue sections. Histochem J 11: 447-453.

JUNQUEIRA LCU, COSSERMELLI W AND BRENTANI R. 1978. Differential staining of collagens type I, II, and III by Sirius Red and polarization microscopy. Arch Histol Jpn 41: 267-272.

MCDEVITT CA AND WEBBER RJ. 1990. The ultrastructure and biochemistry of meniscal cartilage. Clin Orthop Relat R 252: 8-18.

MIKIC ZD, BRANKOV MZ, TUBIC MV AND LAZETIC AB. 1993. Allograft meniscus transplantation in the dog. Acta Orthop Scand 64: 329-332.

MikiC ZD, BRANKOV MZ, TUBIC MV AND LAZETIC AB. 1997. Transplantation of fresh-frozen menisci: an experimental study in dogs. Arthroscopy 13: 579-583.

MONTES GS, KRISZTAN RM, SHIGIHARA KM, TOKORO R, MOURÃo PAS AND JUNQUEIRA LCU. 1980. Histochemical and morphological characterization of reticular fibers. Histochemistry 65: 131-139.

RECKERS LJ, FAGUNDES DJ, COHEN M, RAYMUNDO JLP, MOREIRA MB AND PAIVA VC. 2005. Effects of different preservation temperatures and periods menisci cellularity in rabbits. Acta Cir Bras 20: 428-433.

RECKERS LJ, PAIVA VC AND RAYMUNDO JLP. 2009. Correlation between different temperatures and storage periods in collagen fibers of the rabbit meniscos. Rev Bras Med 66: 30-36.

RIJK PC. 2004. Meniscal Allograft Transplantation, Part I: Background, Results, Graft Selection and Preservation, and Surgical Considerations. Arthroscopy 20: 728-743.

RIJK PC AND VAN NOORDEN CJF. 2002. Structural analysis of meniscal allografts after immediate and delayed transplantation in rabbits. Arthroscopy 18: 995-1001.

SOMER L AND SOMER T. 1983. Is the meniscus of the knee joint a fibrocartilage? Acta Anat 116: 234-244.

Starke C, Kopf S, Petersen W AND BeCKer R. 2009. Meniscal Repair. J Arth Rel Surg 25: 1033-1044.

TUCKER B, KHAN W AND AL-RASHID M. 2012. Tissue Engineering for the Meniscus: A Review of the Literature. Open Orthop J 6: 348-351.

TULBERG-REINERT H AND JUNDT G. 1999. In situ measurement of collagen synthesis by human bone cells with Sirius Red-based colorimetric microassay: effects of transforming growth factor $\beta 2$ and ascorbic acid 2-phosphate. Histochemi Cell Biol 112: 271-276.

VILELA LM, DEL CARLO RJ, OLIVEIRA RC, REIS AMS, BRITO AFS, MELO FILHO E, FERRARI GF AND GALVÃO SR. 2013. Mechanical properties of rabbit meniscal allografts after glycerin preservation and rehydration in $\mathrm{NaCl}$ 0.9\%. Cienc Rural 43: 2234-2239.

VILELA LM, DEL CARlo RJ, SILVA JCP AND MATTA SLP. 2010a. Structure and cellularity of the fresh menisci (Oryctolagus cuniculus) of rabbits and the menisci preserved in glycerin. Pesq Vet Bras 30: 295-300.

Vilela LM, Del CARlo RJ, Silva JCP, MatTa SLP, RODRIGUES MD AND REIS AMS. 2010b. Evaluation of the collagen fibers of the fresh meniscus and the meniscuses preserved in glycerine: Experimental study in rabbits (Oryctolagus cuniculus). Pesq Vet Bras 30: 321-327.

Wirth CJ, Peters G, Milachowski KA, Weismeier KG AND KOHN D. 2002. Long-term results of meniscal allograft transplantation. Am J Sports Med 30: 174-181.

XING X, JiAKUO Y AND JIYING Z. 2005. Type I, II, III \& $\mathrm{X}$ collagen expression in meniscus and articular cartilage and immune reaction study after xenogenic and allogenic meniscus transplantation in rabbits. Chinese J Sports Med 1: 4-8.

ZAMBRANO NZ, MONTES GS, SHIGIHARA KM, SANCHEZ EM AND JUNQUEIRA LCU. 1982. Collagen arrangement in cartilages. Acta Anat 113: 26-38. 